\title{
Molecular detection of cytomegalovirus, herpes simplex virus 2, human papillomavirus $16-18$ in Turkish pregnants
}

\begin{abstract}
Objective: Human cytomegalovirus (CMV) is the most common cause of viral intrauterine infections in the world. Herpes simplex virus type 2 (HSV-2) and human papillomavirus (HPV) are the main agents of viral sexually transmitted diseases, which cause genital ulcers and genital warts, respectively. HPV infection has been linked to the majority of the anogenital malignancies. The aim of this study was to detect the existence of CMV, HSV-2 and HPV type 16-18 in Turkish pregnants by using sensitive molecular assays. Methods: One hundred thirty-four women (18-41 years old; mean age \pm SD: $27 \pm 8$ ) applied to outpatient clinic of Obstetrics and Gynecology, in between 18th - 22nd weeks of their pregnancy and a control group of 99 healthy women (15-39 years old; mean age \pm SD: $24 \pm 8$ ) were included in the study. Cervical smear samples were used for DNA extraction. CMV, HSV-2 and HPV 16-18 detections were carried out by real time PCR and in house PCR method, respectively. Results: Three patients $(3 / 134 ; 2.2 \%)$ were found to be positive for each HPV and HSV-2. Dual infection with HPV and HSV was found in just one patient. HPV 18 was detected in all positive samples. CMV was found to be positive in two patients $(2 / 134 ; 1.4 \%)$. Conclusion: HPV, HSV and CMV must be screened due to high prevalence of these viruses in pregnants by using sensitive molecular methods.
\end{abstract}

Keywords: pregnancy; infection; polymerase chain reaction.

[Braz J Infect Dis 2010;14(6):569-574]@Elsevier Editora Ltda.

\section{INTRODUCTION}

Cytomegalovirus (CMV) is the most common cause of congenital infections affecting $0.5 \%$ to $2 \%$ of all live births in the developed world. ${ }^{1}$ Intrauterine infection occurs in up to $50 \%$ of pregnancies following primary maternal infection, and $10 \%$ of the infected infants are symptomatic at birth., ${ }^{2,3}$ However nearly 10\%-15\% of the asymptomatic newborns develop late sequelae, particularly sensorineural hearing loss and neurodevelopmental disorders. ${ }^{4}$

Genital herpes continues to be a public health problem in both developed and developing countries. Prevalence of HSV-2 in different populations has shown various results from less than $10 \%$ to more than $40 \% .{ }^{5}$ Laboratory confirmation for clinical diagnosis of HSV-2 is important, particularly as there are other conditions which present similarly to genital herpes, while atypical presentations of genital herpes also occur. ${ }^{6}$
Uterine cervix carcinoma is the second most common type of female cancers and also the second highest mortality cause for women. Human papillomavirus (HPV) being detected in close to $99.7 \%$ of cervical squamous cell carcinomas is imputed to be a necessary factor that causes cervix carcinoma. Hormones and their metabolism alteration have also been implicated as cofactors in HPV proliferation and the cervical cancer pathogenesis. It is well known that high risk HPV infections are more frequent in pregnant women. ${ }^{7-9}$ The polymerase chain reaction (PCR) technology for CMV, HSV, HPV detection is now highly sensitive and can detect viral DNA in exfoliated cells irrespective of the sampling method used. ${ }^{10}$

The aim of this study was to detect CMV, HSV-2, and HPV type 16-18 from cervical smear samples of pregnant women by PCR based methods and to improve an algorithm for follow-up of positive patients.
Authors

Bedia Dinc

Gulendam Bozdayi²

Aydan Biri ${ }^{3}$

Ayse Kalkanci

Bora Dogan $^{1}$

Nuray Bozkurt ${ }^{3}$

Seyyal Rota ${ }^{4}$

${ }^{1} \mathrm{MD}$, Department of Medical Microbiology, Faculty of Medicine, Gazi University, Ankara, Turkey. ${ }^{2} \mathrm{MD}, \mathrm{PhD}$, Associate Professor. Department of Medical Microbiology, Faculty of Medicine, Gazi University, Ankara, Turkey.

${ }^{3} \mathrm{MD}$, Associate Professor.

Department of Obstetrics and Gynecology, Faculty of

Medicine, Gazi University,

Ankara, Turkey

${ }^{4} \mathrm{MD}$, Professor.

Department of Medical

Microbiology, Faculty of

Medicine, Gazi University, Ankara, Turkey.

Submitted on: 02/18/2010 Approved on: 08/30/2010

Correspondence to: Bedia Dinc, MD Gazi University, Faculty of Medicine,

Department of Medical Microbiology,

Dekanlik Binasi, 2. Kat, Besevler, Ankara, Turkey, 06500

Tel: +90 3122024628 Fax: +90 3122124647 E-mail: bhdogan@yahoo. com

We declare no conflict of interest. 


\section{MATERIAL AND METHODS}

\section{Study group}

This study was performed at the Gynecology and Obstetrics Outpatient Clinic at Gazi University Hospital, Ankara, Turkey. One hundred thirty-four women (18-41 years old; mean age \pm SD: $27 \pm 8$ ) applied to outpatient clinic, in between 18th - 22nd weeks of their pregnancy and a control group of 99 healthy women (15-39 years old; mean age \pm SD: $24 \pm 8$ ) followed for routine prenatal visit, were included in the study. Cervical smear samples were used to detect CMV, HSV-2 and HPV. All the patients and the control group answered a questionnaire including age of first sexual intercourse, number of sexual partners and condom use.

\section{Specimen sampling and preservation}

Cervical smear samples collected by sterile swabs were sent to the laboratory in phosphate buffered saline (PBS) $(\mathrm{pH}$ 8.6). The samples in PBS were vortexed and stored in $-86^{\circ} \mathrm{C}$ until they were tested. And $10 \mathrm{~mL}$ of blood was taken from each patient for serological examination of HSV-2.

\section{DNA extraction method for HPV, HSV and CMV}

Following the centrifugation at 13,000 rpm for $3 \mathrm{~min}$, the samples in PBS were treated with lysis solution containing $20 \mathrm{mg} / \mathrm{mL}$ proteinase $\mathrm{K}$ [20 mM (NH4)2SO4, 75 $\mathrm{mM}$ Tris $\mathrm{HCl}$ ( $\mathrm{pH} \mathrm{8.8)} \mathrm{0,1 \%} \mathrm{Tween} \mathrm{20].} \mathrm{After} \mathrm{discarding}$ the supernatant, precipitate was extracted by phenolchloroform isoamyl alcohol method. ${ }^{11}$ Precipitation of DNA was succeeded by using absolute ethanol including $3 \mathrm{M}$ sodium acetate at $-20^{\circ} \mathrm{C}$ overnight. On the following day, samples were mixed with $70 \%$ alcohol and dried. After drying, they were incubated on dry block at $55^{\circ} \mathrm{C}$ for $10 \mathrm{~min}$ and then $50 \mu \mathrm{L}$ sterile deionised water was added.

\section{Amplification of HPV DNA}

The primers used in this study were the consensus primers for all HPV genotypes and were chosen from L1 location of HPV genome which is associated with major viral capsid protein metabolism. MY09/MY11 primers were used for amplification of HPV. ${ }^{12}$ Caski cell DNA was used as a positive control. ${ }^{13}$ During all amplification procedure, a negative control including no targeted DNA was used. Amplification procedure was performed by adding $5 \mu \mathrm{L}$ extracted DNA to a mixture of $45 \mu \mathrm{L}$ including $100 \mathrm{mM}$ from each dNTP (dATP, dCTP, dGTP, dTTP) 100 pmol from each primer and 1 unit of Taq DNA polymerase enzyme (DNA mp ltd., Hants, UK) in $4 \mathrm{mM} \mathrm{MgCl} 2,50 \mathrm{mM} \mathrm{KCl}$, and $10 \mathrm{mM}$ Tris $\mathrm{HCl}(\mathrm{pH} 9.0)$.

A thermal cycler programme with 35 cycles including initial denaturation at $94^{\circ} \mathrm{C}$ for $5 \mathrm{~min}$, denaturation at $94^{\circ} \mathrm{C}$ for 20 seconds, annealing at $55^{\circ} \mathrm{C}$ for 45 seconds and extension at $72^{\circ} \mathrm{C}$ for $1 \mathrm{~min}$, followed by $7 \mathrm{~min}$ of final extension at $72^{\circ} \mathrm{C}$ was performed. PCR products were analyzed on agarose gel stained with ethidium bromide and bands were detected with UV transluminator encompassing $450 \mathrm{bp}$ for HPV. ${ }^{11}$

\section{Genotyping}

MY09/MY14 (5' - CAT ACA CCT CCA GCA CCT AA 3') and MY09/WD74 (5'-GGA TGC TGC ACC GGC TG A-3') specific primers were used for amplification of HPV type 16 and HPV type 18 , respectively. ${ }^{12,14}$

Amplification procedure was performed by adding $5 \mu \mathrm{L}$ pure DNA to a mixture of $95 \mu \mathrm{L}$ including $100 \mathrm{mM}$ from each dNTP (dATP, CTP, dGTP, dTTP) 100 pmol from each primer and 1 unit of Taq polymerase in $4 \mathrm{mM} \mathrm{MgCl} 2,50 \mathrm{mM} \mathrm{KCl} 2$, and $10 \mathrm{mM}$ Tris $\mathrm{HCl}$ ( $\mathrm{pH} 9.0)$. We used a thermal cycler programme for HPV genotyping as described above. PCR products were analyzed on agarose gel stained with ethidium bromide and transluminating band was detected with UV transluminator encompassing $110 \mathrm{bp}$ for HPV 16 and 140 bp for HPV 18.

\section{Real-time PCR for CMV and HSV-2}

Real-time PCR reactions were carried out by using Ligthcycler (Roche Diagnostics, Germany). Ligthcycler DNA master hybridization probes kit (Roche) was used for amplification. Taqman probes labeled with FAM at their 5 ' end and labeled with TAMRA as quencher at their 3' end, and specific primer sets for HSV DNA polymerase gene region and CMV pp65 gene region (Table 1) were used for amplifications (Metis Biotechnology Ankara, Turkey).

Table 1. Primers and probes

Agent Region Primers (5 > 3)

HSV DNA polymerase CAT CAC CGA CCC GGA GAG

GGA C

HSV DNA polymerase GGG CCA GGC GCT TGT TGG

TGT A

CMV pp65 CTT GCC CTG GAT GCG ATA CT

CMV pp65 ACG GCT TTA CGG TGT TGT GT

Probes

HSV LC (TaqMan Probe) FAM- CCG CCG AAC TGA GCA

GAC ACC CGC GC -TAMRA

CMV LC (TaqMan Probe) FAM- CGC GAG ACC GTG GAA

CTG CG -TAMRA 
In each assay, five CMV AD 169 DNA standards from $2 \times 10^{2}$ to $2 \times 10^{6} \mathrm{CMV}$ DNA copy $/ \mathrm{mL}$ were used as external standards. A capillary tube containing distilled water instead of DNA was used as negative control in each run. The detection limit was established as $200 \mathrm{CMV}$ DNA copy/mL in blood. Serial dilutions containing $2 \times 10^{2}-2 \times 10^{6}$ HSV DNA were prepared for HSV and a limit was detected as $200 \mathrm{HSV}$ DNA copy $/ \mathrm{mL}$. A negative control was used in each study.

\section{CMV serology}

Anti-CMV IgM antibody: specific IgM responding to CMV in cervicovaginal smear samples was studied with two different methods: microparticle enzyme immunoassay (MEIA) system and its appropriate anti-CMV IgM kit (Imx System, Abbott Laboratories, Abbott Park, IL, USA) and a commercial diagnostic anti-CMV IgM enzyme-linked immunosorbant assay (ELISA) kit (Radim SPA, Pomezia-Rome, Italy).

Anti-CMV IgG antibody: specific IgG responding to CMV in cervicovaginal smear samples was studied with MEIA system and its appropriate anti-CMV IgG kit (Axsym System, Abbott Laboratories, Abbott Park, IL, USA).

CMV IgG avidity test: the cervicovaginal smear sample with $4 \mathrm{U} / \mathrm{mL}$ of anti-CMV IgG were studied with a commercial diagnostic CMV IgG avidity Enzyme immunoassay (EIA) kit (Radim SPA, Pomezia-Rome, Italy) according to the manufacturer's instructions.

\section{HSV serology}

HSV-2 IgM and IgG antibodies were detected by EIA (Meddens Diagnostics B.V., The Netherlands) in the sera samples. Quantitative EIA was performed for HSV 2 IgG Ab according to the manufacturer's instructions.

\section{RESULTS}

\section{Patients and USG findings}

All pregnants and the control group were monogamic and had no history of sexual intercourse before getting married. The reported age at first sexual intercourse was less than 20 years for $98(73.1 \%)$ pregnants, and $67(67.7 \%)$ of control group respectively. Of the 134 pregnants, 32 (23.8\%) and
99 controls 35 (35.4\%) reported ever use of condoms for STDs. Of the 134 pregnants, 22 had abnormal ultrasonographic findings, four oligohydramnios, four ventriculomegaly, three intrauterine growth retardation (IUGR), three IUGR + oligohydramnios, two polyhydramnios, one bilateral choroid plexus cyst greater than $7 \mathrm{~mm}$, one echogenic bowel + choroid plexus cyst, one polihydramnios, one omphalocele, one multiple structural abnormalities and one hydrops fetalis were detected.

Out of three pregnants with IUGR + oligohydramnios, one was found to be positive for CMV. All other pregnants with abnormal ultrasonographic findings were found to be negative for each of the three viruses. No abnormal USG findings were detected in any of the control group.

\section{Serology for CMV and HSV}

Anti-CMV IgM was found to be negative in all of the cervicovaginal smear samples. In all of the samples studied, one cervicovaginal smear sample was found to be $4 \mathrm{U} / \mathrm{mL}$, with negative result. Because both tests for anti-CMV IgM, and CMV IgG were designed for only serum evaluation, the cut-off values for smear may be lower than the cut-off values $(10 \mathrm{U} / \mathrm{mL})$ accepted for serum. In this respect the cervicovaginal smear sample with $4 \mathrm{U} / \mathrm{mL}$ of anti-CMV IgG value was also approved as positive and studied with CMV IgG avidity test.

CMV IgG avidity test: according to the kit that we used, we considered the values below $35 \%$ as a low avidity, values between $35 \%$ and $45 \%$ as a gray zone and above $45 \%$ as a high avidity. Low avidity is a finding in favor of a primary acute infection. The cervicovaginal smear sample with $4 \mathrm{U} / \mathrm{mL}$ of antiCMV IgG value was also studied with CMV IgG avidity test and again low avidity (21\%) was found. This situation was also suggested a primary acute infection.

HSV-2 Ig M and IgG were positive in the sera samples of 6 $(4.4 \%)$ and $9(9 \%)$ of pregnants, respectively.

\section{In house PCR and RT PCR for CMV, HPV and HSV-2}

CMV DNA was found to be positive in two (1.5\%) of pregnant women by real-time PCR. In control group there was no CMV DNA positivity. In one of the CMV positive pregnant women, there were abnormal USG findings (oligohydroamnios and in utero growth retardation) (Table 2).

Table 2. One of two CMV positive pregnants had abnormal ultrasonographic finding. CMV DNA was negative for HPV type 18 positive 3 pregnants, while one of 3 was detected positive for HSV-2

\begin{tabular}{lcccccc}
\hline & \multicolumn{2}{c}{ CMV } & \multicolumn{2}{c}{ HSV-2 } \\
\hline HPV Type 18 & Positive & Negative & Positive & Negative & Total \\
& Positive & - & $3(2.1 \%)$ & $1(0.7 \%) * *$ & $2(1.4 \%)$ & $3(2.1 \%)$ \\
& Negative & $2(1.4 \%)$ & $132(98.6 \%)$ & $2(1.4 \%)$ & $132(98.6 \%)$ & $131(97.8 \%)$ \\
\hline Abnormal USG & $1 *(5 \%)$ & $20(95 \%)$ & - & $21(100 \%)$ & $21(100 \%)$ \\
\hline Total & $2(1.4 \%)$ & $132(98.6 \%)$ & $3(2.1 \%)$ & $131(97.8 \%)$ & $134(100 \%)$
\end{tabular}

*: abnormal USG findings

$* *$ dual infections (HPV and HSV-2) 
Three $(3 / 134 ; 2.2 \%)$ of pregnant women were found to be positive for only HPV 18. No other types of HPV were detected in any of the pregnants (Figure 1). In control group, there was no HPV DNA positivity.

Figure 1: A; (HPV) M: fX174 DNA / Hae III marker. Lanes 1, 2, 3: HPV positive patients. Lanes 4, 5: Negative control, B; (HPV type 18), M: fX174 DNA / Hae III marker. Lanes 1, 2, 3: HPV type 18 positive patients. Lane 4: Positive control. Lane 5: Negative control.

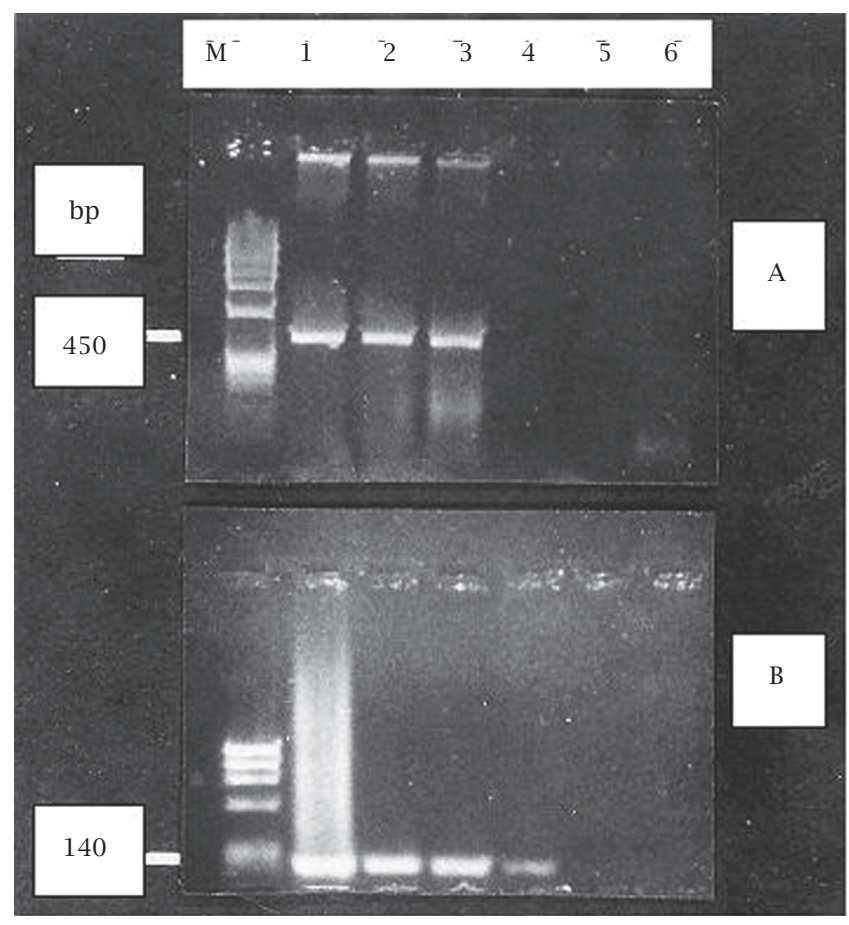

Three $(3 / 134 ; 2.2 \%)$ of the samples from the pregnant women were found to be positive for HSV-2. Dual infection with HPV and HSV positivity was found in one patient. Any gynecological examination findings were not found out in favor of HPV and HSV in any of the patients (Table 2).

None of the pregnants and the control group had triple infection with CMV, HSV-2 and HPV. While there was no positivity for both CMV and HPV, HSV was found to be positive in $2(2 \%)$ samples in control group.

\section{DISCUSSION}

In this study, of the 134 pregnant women, CMV DNA was found to be positive in two (1.5\%) patients, while no CMV DNA positivity was found by real-time PCR in control group. In one of the CMV positive pregnant women, there were abnormal USG findings (oligohydroamnios and in utero growth retardation). She was followed for IUGR and in utero exitus happened during the 20th week of pregnancy.
Autopsy and CMV PCR from these materials could not be performed since the family did not give permission. The other CMV DNA positive pregnant woman gave a healthy birth and no problems occurred with the mother and baby during follow-up.

Previous studies have shown that the incidence of CMV excretion from cervix increases while pregnancy proceeds. ${ }^{15}$ In our study group, the patients were at their second trimester. In Turkey, Koksal et al. ${ }^{16}$ Kaleli et al. ${ }^{17}$ and Satilmis et al. ${ }^{18}$ reported the prevalence of CMV IgG in pregnant women as $79 \%, 94.7 \%$ and $98.5 \%$, respectively. CMV IgM positivity in pregnancy was reported as $0.66 \%$ by Kaleli et al.. ${ }^{17}$ It is determined that virus spread with asymptomatic infection is frequent among pregnant women and virus can be isolated from cervical mucus and urine of $2 \%-28 \%$ of pregnant women. ${ }^{19}$ There are several potential routes of infection of the placenta during pregnancy, including ascending infection from the genital tract as well as hematogenous transmission. As CMV secretion from cervix increases during pregnancy, a large spectrum of cells of the fetus is infected by CMV. The major target fetal organs for CMV infection are the lungs, pancreas, kidneys and the liver but comparing with these organs, CMV DNA level determined in uterine tissue and cervical smear is higher. ${ }^{20}$

In our study, 134 pregnant women were screened for HSV-2 DNA. Three (2.2\%) pregnant women and $2(2 \%)$ women in control group were found to be positive in favour of HSV-2. In our country, HSV-2 is rarely seen due to the monogamy in the sexual relations. Genital herpes resulting from HSV-2 infection of the urogenital tract is a worldwide public health problem. European investigations of pregnant women have shown overall prevalence of HSV-2 to range between $9 \%$ and $33 \% .{ }^{21}$ HSV-2 DNA prevalence was reported as $2 \%$ in Turkish pregnants recently. ${ }^{22}$ Transmission of HSV is usually via direct contact with lesion while HSV-2 is classically transmitted sexually. ${ }^{6}$ The women most at risk for mother to child transmission are the ones who are previously uninfected. New onset HSV infection in late pregnancy carries a 30\%-50\% risk of neonatal infection since there is not an adequate time for antibodies to develop and suppress the viral replication before labor, while infection in early pregnancy carries a risk of less than $1 \%{ }^{6,23}$ Fortunately the risk of fetal infection in recurrent episodes is nearly $2 \% .{ }^{24}$ Risk for baby usually happens during delivery via contact with genital lesions with recurrent episodes of viral shedding; therefore, caesarean section is recommended in these cases. ${ }^{25}$ In pregnant population, real-time PCR has some advantages, making results available at a much earlier time, thus significantly reducing the need for empirical treatment. ${ }^{23,26}$ Dual infection with HPV and HSV positivity was found in one patient in our study. Any gynecological examination findings were not found out in favor of HPV and HSV in any of the patients. Of the three 
HSV-2 DNA positive patients, all were HSV-2 IgM positive with no physical symptoms. These patients did not have a history of condom use before pregnancy and their first sexual intercourse were after the age of 20. Although they were asymptomatic, caesarean section was recommended for HSV positive three patients in our hospital and no problems occurred during the follow up of the mothers and babies.

Studies about HPV show that its transmission mode remains unclear. HPV is positive in the airways of neonates and in maternal genital condylomas, which suggests that it is transmitted in the birth canal, from mothers with genital condylomas. ${ }^{27}$ Since the serologic diagnosis of HPV is inadequate, molecular diagnosis has been more popular in recent years. ${ }^{28}$ Epidemiological studies revealed different results in pregnant women. Smith et al. ${ }^{29}$ Gajewski et al..$^{30}$ and Takakuwa et al..$^{31}$ have found out $29 \%, 26 \%$ and $12.5 \%$ of HPV positivity respectively in pregnant women taking routine obstetric care. In a study performed in our country, HPV DNA was found as $9.5 \%$ by PCR. One patient was found type $16 / 30$, the others were untyped. ${ }^{32}$ We have found that $2.2 \%$ of the patients were positive for HPV 18 in our study where Smith et al..$^{29}$ found that $2.6 \%$ of the patients were positive in favor of HPV 18. The association between HSV-2 and HPV 18 was found in one of the pregnant women. This association may be due to the similar transmission route of both viruses. During the neonatal follow-up of baby HPV DNA was not found in the laryngeal swab by Real Time PCR.

\section{CONCLUSION}

Since HPV is considered as an infection predisposed to malignancies, HPV detection with molecular methods should be considered as a routine screening test for women applied to obstetrics and gynecology clinics. This screening policy should also contain CMV and HSV infections because of their potential transmission risks for the baby. We suggest that our assays provide useful information about CMV, HSV, HPV infections in the fetus and the neonate; and obstetricians have to make informed decisions about the management of pregnancies complicated by CMV, HSV, and HPV infections.

\section{REFERENCES}

1. Azam AZ, Yvan V, Fawer CL et al. Prenatal diagnosis of congenital cytomegalovirus infection. Obst and Gynecol 2001; 97:443-8.

2. Yamamoto AY, Mussi-Pinhata MM, Pinto PCG et al. Usefulness of blood and urine samples collected on filter paper in detecting cytomegalovirus by the polymerase chain reaction technique. J Virol Meth 2001; 97:159-64.

3. Schleiss MR, Bourne N, Bravo FJ et al. Quantitative-competitive PCR monitoring of viral load following experimental guinea pig cytomegalovirus infection. J Virol Meth 2003; 108:103-10.
4. Gindes L, Teperberg-Oikawa M, Sherman D et al. Congenital cytomegalovirus infection following primary maternal infection in the third trimester. BJOG 2008; 115:830-5.

5. Eskild A, Jeansson S, Hagen JA et al. Herpes simplex virus type-2 antibodies in pregnant women: the impact of the stage of pregnancy. Epidemiol Infect 2000; 125:685-92.

6. Kriebs JM. Understanding herpes simplex virus: transmission, diagnosis and considerations in pregnancy management. J Midwifery Womens Health 2008; 53:202-8.

7. Armbruster-Moraes E, Ioshimoto LM, Leao E, Zugaib M. Prevalence of high risk human papillomavirus in the lower genital tract of Brazilian gravidas. Intern J Gynecol and Obst 2000; 69:223-7.

8. Chan PK, Chang AR, Tam WH et al. Prevalence and Genotype Distribution of Cervical Human Papillomavirus Infection: Comparison Between Pregnant Women and Non-Pregnant Controls. Journal of Medical Virology 2002; 67:583-8.

9. Mayeaux EJ. Reducing the economic burden of HPV-related diseases. J Am Osteopath Assoc 2008; 108:52-7.

10. De Sanjose S, Boch XF, Munoz N et al. Screening for genital human papillomavirus: results from an international validation study on human papillomavirus sampling techniques. Diag Mol Path 1999; 8:26-31.

11. Maniatis T, Fritsch EF. Molecular Cloning. In: J Sambrook ed. A Laboratory Manual. New York: 1990.

12. Baay MFD, Quint WGV, Koudstaal J et al. Comprehensive study of several general and type-specific primer pairs for detection of human papillomavirus DNA by PCR in paraffin-embedded cervical carcinomas. J Clin Microbiol. 1996; 34:745-7.

13. Tuncer S, Ustaçelebi S. Detection of Human Papillomavirus Types 16 and 18 by Polymerase Chain Reaction in Cervical Biopsy Specimens. Flora 1996; 1:40-4.

14. Poljak M, Seme K. Rapid detection and typing of human papillomaviruses by consensus polymerase chain reaction and enzymelinked immunosorbent assay. J Virol Meth 1996; 56:231-8.

15. Chandler SH, Alexander ER, Holmes KK. Epidemiology of cytomegalovirus infection in a heterogeneous population of pregnant women. J Infec Dis 1985; 152:249-56.

16. Koksal I, Alnaci M, Kardes OB, Aydemir V. Toxoplasma, rubella and cytomegalovirus seropositivity ratios among adults in Eastern Black Sea Region. Turk Bullet Microb 1994; 28:58-61.

17. Kaleli B, Kaleli I, Yurdakul B, Aksit F. Rubella and Cytomegalovirus Infection in Pregnancy. Turk J Infect. 1997; 11:325-7.

18. Satilmis A, Gura A, Ongun $\mathrm{H}$ et al. CMV seroconversion in pregnants and the incidence of congenital CMV infection. Turk J Pediatr. 2007; 49(1):30-6.

19. Gibbs RS, Sweet RL. Maternal and fetal infectious disorders. In: Creasy RK, Resnik R eds. Maternal Fetal Medicine. Philadelphia: W.B. Saunders, 1994.

20. Fisher S, Genbacev O, Maidji E, Pereira L. Human cytomegalovirus infection of cytotrophoblasts in vitro and in utero: Implications for transmission and pathogenesis. Journal of Virology 2000; 74(15):6808-20.

21. Gaytant MA, Steegers EAP, Van Laere M et al. Seroprevalence of herpes simplex virus type 1 and type 2 among pregnant women in the Netherland. Sex Transm Dis. 2002; 29:710-4.

22. Rota S, Bozdayi G, Dogan B, Dinc B. Investigation of herpes simplex virus DNA by real-time polymerase chain reaction in the clinical samples. Bulletin of Microbiology 2004; 38:233-9.

23. Perkins D, Chong H, Irvine B, Domagalski J. Genital co- infection with herpes simplex viruses type 1 and 2; comparison of real time PCR assay and traditional viral isolation methods. J Cell Mol Med 2007; 11(3):581-4. 
24. Poeran J, Wildshut $\mathrm{H}$, Gaytant $\mathrm{M}$ et al. The incidence of neonatal herpes in The Netherlands. J Clin Virol 2008; 42 (4):321-5.

25. Moss NJ, Harper CC, Ahrens K et al. Predictors of incident herpes simplex virus type 2 infections in young women at risk for unintended pregnancy in San Fransisco. BMC Infect Dis 2007; 7:113.

26. Gouarin S, Gault E, Vabret A et al. Real-Time PCR quantification of human cytomegalovirus DNA in amniotic fluid samples from mothers with primary infection. J Clin Microbiol 2002; 40:1767-72.

27. Smith EM, Johnson SR, Pignatari S et al. Perinatal vertical transmission of human papillomavirus and subsequent development of respiratory tract papillomatosis. Ann Otol Rhinol Laryngol 1991; 100:479-83.
28. Collier L, Oxford J Papovaviridea. In: Collier L. ed. Human Virology. New York: Oxford University Press, 2000.

29. Smith EM, Ritchie JM, Yankowitz J et al. HPV prevalence and concordance in the cervix and oral cavity of pregnant women. Infect Dis Obstet Gynecol 2004; 12:45-56.

30. Gajewski M, Wielgos M, Kami ski P et al. The occurance of genital types of Human papillomavirus in normal pregnancy and in pregnant renal transplant recipients. Neuro Endocrinol Lett 2006; 27:529-34.

31. Takakuwa K, Mitsui T, Iwashita M et al. Studies on the prevalence of Human papillomavirus in pregnant women in Japan. J Perinat Med 2006; 34:77-9.

32. Guney AI, Ince U, Kullu S et al. Detection and typing of human papillomavirus in cervical specimens of Turkish women. Eur J Gynaecol Oncol 1997; 18(6):546-50. 